DE DE GRUYTER

OPEN

DOI 10.2478/pesd-2018-0006

PESD, VOL. 12, no. 1, 2018

\title{
RESEARCH ON THE INFLUENCE OF TEMPERATURE ON BEECH CROPS RAISED IN NURSERIES.
}

\section{Antonia ODAGIU ${ }^{1}$, Ilie COVRIG ${ }^{1}$, Camelia OROIAN ${ }^{1}$, Mădălina Florina PRESECAN ${ }^{1}$}

Key words: frost, beech seedlings, seedling loss, nursery, emergence percentage, maximum protective effect

\begin{abstract}
A particularly important determining factor for the installation and development of seedlings during the early years is their ability to withstand deviations from the normal regime of the climatic elements. Beech seedlings have poor resistance to extreme climate changes. The development of seedlings during the first years can be strongly affected by extreme temperatures. During the research, it was noticed that the frosts which may occur during the second half of April and in early May, before foliation, can cause significant injuries to the plantlets. A large part of the beech seedlings appear in early spring, approximately $7-10$ days before the foliation of beech trees. The effects of these frosts have also been felt in the nurseries located in the area of the Sovata Forestry, in the case of crops sown in the autumn of the previous year in the Isuica Nursery, situated at an altitude of $520-530 \mathrm{~m}$, in the vicinity of Săcădat Creek, and in the case of Solar II Nursery, situated in the village Câmpul Cetaţii, at an altitude of $610 \mathrm{~m}$. The latter nursery is neighbored by the trout farm from Câmpul Cetăţii to the south, by the secondary school to the west, by private residences and estates to the east and by the village road of Câmpul Cetăţii to the north. In both nurseries the emergence percentage of the crops at the end of April was over $90 \%$. Based on the average number of seedlings emerged per area unit, the losses recorded as a result of the frosts from 3-4 May were, in the case of the Isuica Nursery, $89 \%$ on 10 May, reaching $97 \%$ towards the end of the month. Unlike in the Isuica Nursery, in the Solar II Nursery the losses due to the frost of 3 May were not uniform. The area that was least affected by frost was situated in the immediate proximity of the larch curtain and the secondary school building, where the percentage of losses did not exceed $2 \%$. Moving away from the larch curtain, the percentage increased progressively, reaching, at about $24 \mathrm{~m}$ (on the

1 University of Agricultural Sciences and Veterinary Medicine, Cluj-Napoca, Romania, ilie_covrig@yahoo.com
\end{abstract}


diagonal of the plot), as high as $87 \%$. This percentage was close to that of the (uniform) losses registered in the Isuica Nursery. Thus, the maximum protective effect was recorded up to a distance of about $9 \mathrm{~km}(0.75 \mathrm{H})$, where $\mathrm{H}$ represents the height of the larch curtain). From this distance, the protective effect exerted by the larch curtain (and the secondary school building with a height of $8 \mathrm{~m}$ ) started to decrease. While at a distance of about $1 \mathrm{H}$, the percentage of losses was $17 \%$, at $1.5 \mathrm{H}$ it reached $61 \%$, and at approx. $2 \mathrm{H}$ it neared $90 \%$.

\section{Introduction}

The research was conducted in the area of the Sovata Forestry, located in the upper Basin of the Niraj and of the Small Tărnava. Beech trees find here particularly favorable climate and vegetation conditions and, in general, they regenerate easily, in a natural way. By contrast, spruce trees regenerate with great difficulty naturally, as a result of the intensified changes caused by human interventions in forest life. Moreover, forest areas with sessile oak trees regenerate naturally with very great difficulty, on the one hand, because of the changes caused in forest life by the anthropogenic factor, and on the other hand, due to the fact that in this area fructification of the sessile oak is very rare. Under these circumstances, the research focused on the regeneration of beech trees.

\section{Research material and method}

In organizing and conducting field research, we focused on areas in which seedlings were installed following the abundant fructification of 1994, as well as of the previous years. We also focused on the installation and development of the young plantlets emerged in the spring of 2000, a result of the fructification from the autumn of 1999. Given the fact that late frosts were recorded in the area in the spring of 2000, observations and measurements were made regarding the evolution of some practical and experimental cultures, installed in the Câmpul Cetăţii greenhouse, as well as in Isuica and Solar II nurseries from Câmpul Cetăţii. Thermometers measuring maximum and minimum values were used for determining the temperature at ground level.

\section{Findings and discussion}

The resistance of the young plantlets and seedlings to extreme temperatures. It is well known that a large part of beech seedlings appear very early in spring, about $7-10$ days before the foliation of beech trees.Thus, in the spring of 2000, in the landscape units 74B of U.P. III and 127 of the U.P. V, situated at an altitude of $660 \mathrm{~m}$ and, respectively, of $600 \mathrm{~m}$, due to the high temperatures registered in the second half of April (average values rose from 
Tab. 1. The damage caused to the beech seedlings by the frosts of 3-4 May 2000

\begin{tabular}{|c|c|c|c|c|c|}
\hline \multirow[t]{2}{*}{$\begin{array}{l}\text { UP } \\
\text { u. a. }\end{array}$} & \multirow[t]{2}{*}{$\begin{array}{l}\text { Product } \\
\text { market no. }\end{array}$} & \multirow{2}{*}{$\begin{array}{c}\text { No. of seeds } \\
\text { found in the } \\
\text { autumn of } 1999 \\
\text { pcs/sqm }\end{array}$} & \multicolumn{2}{|c|}{$\begin{array}{l}\text { No. of plantlets } \\
\text { pcs/sqm }\end{array}$} & \multirow[t]{2}{*}{$\begin{array}{c}\text { Frost-induced loss } \\
\%\end{array}$} \\
\hline & & & $\begin{array}{c}\text { La } 24.04 . \\
200\end{array}$ & $\begin{array}{c}\text { La 07-08. } 05 . \\
2001\end{array}$ & \\
\hline \multicolumn{6}{|c|}{ RESEARCH AREA II. } \\
\hline \multirow{4}{*}{$\begin{array}{l}\mathrm{VI} / \\
127\end{array}$} & 1 & 12 & 8 & 3 & 62 \\
\hline & 2 & 14 & 11 & 5 & 55 \\
\hline & 3 & 11 & 14 & 4 & 71 \\
\hline & 4 & 24 & 17 & 9 & 47 \\
\hline \multirow{12}{*}{$\begin{array}{l}\mathrm{VI} / \\
127\end{array}$} & 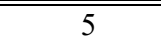 & 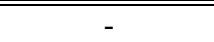 & 2 & - & 100 \\
\hline & 6 & 15 & 12 & 3 & 75 \\
\hline & 7 & 27 & 15 & 11 & 27 \\
\hline & 8 & 3 & - & - & - \\
\hline & 9 & 11 & 5 & 2 & 60 \\
\hline & 10 & 13 & 9 & 5 & 44 \\
\hline & 11 & 14 & 12 & 3 & 75 \\
\hline & 12 & 7 & 2 & - & 100 \\
\hline & 13 & 11 & 17 & 1 & 94 \\
\hline & 14 & 5 & - & - & - \\
\hline & 15 & 8 & 4 & - & 100 \\
\hline & 16 & 6 & 2 & - & 100 \\
\hline \multicolumn{2}{|c|}{$\begin{array}{l}\text { AVERAGE } \\
\text { VALUE }\end{array}$} & 11.3 & 8.1 & 2.9 & 72 \\
\hline \multicolumn{6}{|c|}{ RESEARCH AREA V. } \\
\hline \multirow{16}{*}{$\begin{array}{l}\text { III. / } \\
74 \mathrm{~B}\end{array}$} & 1 & 4 & 5 & - & 100 \\
\hline & 2 & 7 & 6 & 2 & 67 \\
\hline & 3 & 2 & - & - & - \\
\hline & 4 & 6 & 2 & - & 100 \\
\hline & 5 & 11 & 13 & 4 & 69 \\
\hline & 6 & 17 & 14 & 3 & 79 \\
\hline & 7 & 28 & 21 & 7 & 67 \\
\hline & 8 & 13 & 7 & 2 & 71 \\
\hline & 9 & 16 & 12 & 4 & 67 \\
\hline & 10 & 8 & 3 & - & 100 \\
\hline & 11 & 11 & 12 & 5 & 58 \\
\hline & 12 & 29 & 19 & 5 & 74 \\
\hline & 13 & 18 & 8 & 3 & 63 \\
\hline & 14 & 10 & 3 & 2 & 33 \\
\hline & 15 & 9 & 8 & 7 & 13 \\
\hline & 16 & 21 & 17 & 15 & 12 \\
\hline \multicolumn{2}{|c|}{ AVERAGE VALUE } & 13.12 & 9.4 & 3.7 & 65 \\
\hline
\end{tabular}

$6.2^{\circ} \mathrm{C}$ on April 13 to $12.4{ }^{\circ} \mathrm{C}$ on April 30, and minimum values were also above $0{ }^{\circ} \mathrm{C}$, increasing from $1.6{ }^{\circ} \mathrm{C}$ on 13 April to $6.1-6.3{ }^{\circ} \mathrm{C}$ on 30 April), the 
emergence of plantlets was triggered on 20 April, when traces of snow could be seen in sheltered areas. On the nights of 3 and 4 May, temperatures fell to -4.3 ${ }^{\circ} \mathrm{C}$ and, respectively, $-0.8{ }^{\circ} \mathrm{C}$. On 7 and, respectively, on 8 May, it was found that over $60 \%$ of the plantlets had been destroyed by the frost. The phenomenon was more pronounced in the u.a. 127 of U.P. VI, a surface with southern exposure, in comparison with u.a. 74B of U. P. III, a surface with north-eastern exposure. On this surface, on shaded portions, the damage caused by the same frosts represented $10-13 \%$ (Tab.1).

At altitudes above $850 \mathrm{~m}$, in areas with north-eastern exposure (u.a. 75A of U.P. I) or with northern exposure (u.a. 87B of U.P. II), where the development of the plantlets was still in an incipient stage on 3-4 May (the development of leaflets was not complete), the plantlets did not suffer at all or suffered very little. The effects of the frost from 3 - 4 May 2000 were also felt in the case of the crops installed in the autumn of 1999 in the Isuica and Solar II nurseries, where the emergence of seedlings occurred in a proportion of $90 \%$ by the end of April 2000 (Tab.2).

Tab.2. Damage caused to the beech plantlets by the frosts of $3-4$ May 2000

\begin{tabular}{|c|c|c|c|}
\hline \multirow[t]{2}{*}{$\begin{array}{c}\text { Features } \\
\text { (nursery "version") }\end{array}$} & \multicolumn{2}{|c|}{$\begin{array}{c}\text { Average no. of plantlets } \\
\mathrm{pcs} / \mathrm{sqm}\end{array}$} & \multirow{2}{*}{$\begin{array}{l}\text { The loss on } \\
10.05 .2000 \\
(\%)\end{array}$} \\
\hline & $\begin{array}{l}\text { Before the frost } \\
\text { (after emergence) }\end{array}$ & $\begin{array}{l}\text { After the } \\
\text { frost }\end{array}$ & \\
\hline 0 & 1 & 2 & 3 \\
\hline \multicolumn{4}{|c|}{ A. ISUICA NURSERY } \\
\hline $\begin{array}{l}\text { Plot shaded by spruce branches, } \\
\text { located on a } 1.3 \mathrm{~m} \text { high stand, } \\
\text { central position in the nursery }\end{array}$ & 276 & 29 & 89 \\
\hline \multicolumn{4}{|c|}{ B. NURSERY SOLAR II. } \\
\hline $\begin{array}{l}\text { Plot shaded by spruce branches, } \\
\text { located on a } 1.3 \mathrm{~m} \text { high stand. } \\
\text { Position at the north-west } \\
\text { extremity, on the western side, at } \\
\text { a distance of } 4 \mathrm{~m} \text {, an } 8 \mathrm{~m} \text { wide } \\
\text { building, and a } 12 \mathrm{~m} \text { high larch } \\
\text { curtain } \\
\text { Area I. } \\
\text { Area II. } \\
\text { Area III. } \\
\text { Area IV. } \\
\text { Area V. } \\
\text { Area VI. }\end{array}$ & 346 & $\begin{array}{c}338 \\
287 \\
168 \\
134 \\
59 \\
45\end{array}$ & $\begin{array}{c}2 \\
17 \\
51 \\
61 \\
83 \\
87\end{array}$ \\
\hline
\end{tabular}


The data presented in Table 2 show the level of losses caused by the frost of 3-4 May 2000 in relation to the average number of plantlets emerged per area unit. Observations and measurements with regard to the emergence of the beech crops in the two nurseries were carried out from 20 April until 28 April in the Isuica Nursery, and until 29 April in the Solar II Nursery.

The Isuica Nursery is located at an altitude of $520-530 \mathrm{~m}$, in the vicinity of Săcădat Creek. In the nearby area there is agricultural land. On the northern side there is a clump of spruce trees and a curtain of alder trees, in the area bordered by Săcădat Creek. The plot with beech seedlings was positioned centrally, about $40 \mathrm{~m}$ from the southern and the northern sides of the nursery. As shown in Table 2, given that the distance from the plot to the northern extremity (where the alder curtain and the clump of spruce trees were found) twice exceeded the height of the alder curtain and of the clump of spruce trees, the damage caused by the frost was $89 \%$ on 10.05 .2000 , and it reached $97-98 \%$ by the end of May.The Solar II Nursery is located in the village Câmpul Cetăţii, at an altitude of $610 \mathrm{~m}$. It is neighbored by trout farm from Câmpul Cetăţii to the south, by the secondary school to the west, by private residences and estates to the east and by the village road of Câmpul Cetăţii to the north. On the western side, next to the secondary school, there is a $12 \mathrm{~m}$ high larch curtain. The plot with beech seedlings is positioned at the north-western extremity of the Solar II Nursery, parallel with the secondary school and along the village road of Câmpul Cetăţii (fig. 1).

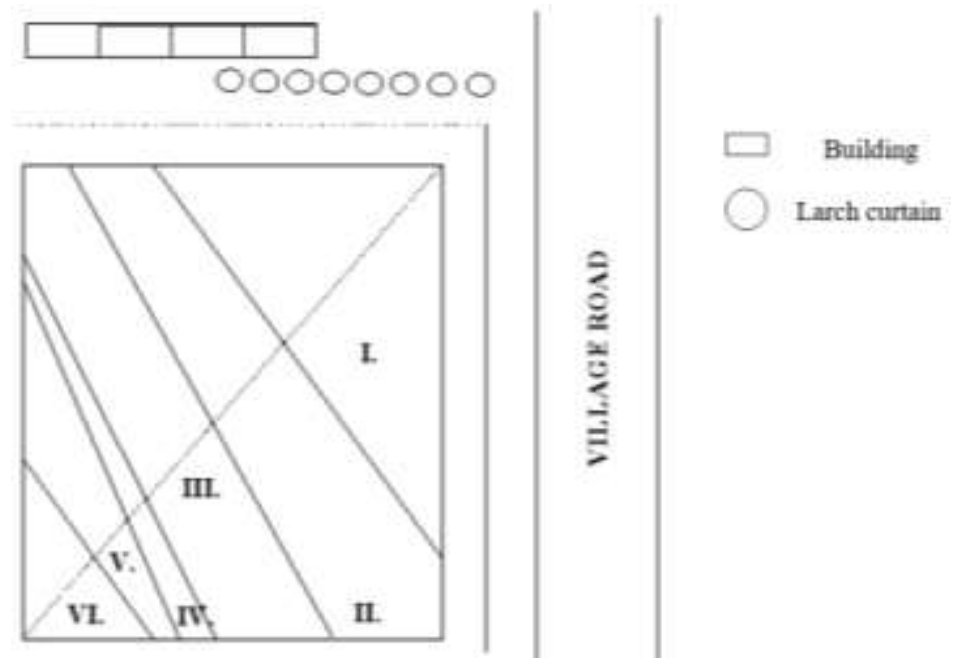

Fig. 1. Sketch of the location of the plot with beech seedlings in the Solar II Nursery, and the areas delineated according to the percentage of loss 
The data listed in Table 2 show that unlike in the Isuica Nursery, in the Solar II Nursery the losses caused by the frost of 3 May 2000 were not uniform. 6 areas have been delineated according to the percentage of losses. The area that was least affected by the frost was located the in the immediate proximity of the larch curtain and of the secondary school building, where the percentage of losses did not exceed $2 \%$, but moving away from the larch curtain, the percentage increased progressively, reaching, at about $24 \mathrm{~m}$ (on the diagonal of the plot), as high as $87 \%$ (fig. 2). This percentage was close to that of the (uniform) losses registered in the Isuica Nursery

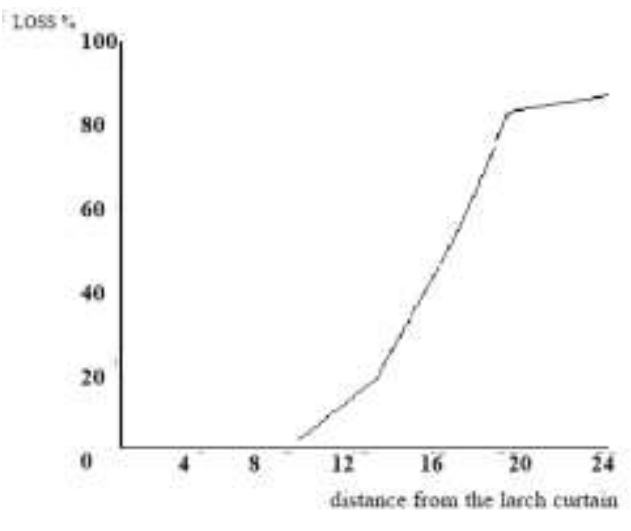

Fig. 2. The variation of losses due to the frost

\section{Conclusions}

To sum up, the maximum protective effect was recorded up to a distance of about $9 \mathrm{~m}(0.75 \mathrm{~h})$, where $\mathrm{h}$ represents the height of the larch curtain). From this distance, the protective effect exerted by the larch curtain (and by the secondary school building, with a height of $8 \mathrm{~m}$ ) decreased, so while at a distance of about $1 \mathrm{~h}$, the percentage of losses amounted to $17 \%$, at $1.5 \mathrm{~h}$ it reached $61 \%$, and at approx. $2 \mathrm{~h}$ it neared $90 \%$.

A particularly important determining factor for the installation and development of seedlings during the early years is their ability to withstand deviations from the normal regime of the climatic elements. Beech seedlings have poor resistance to extreme climate changes. The development of seedlings during the first years can be strongly affected by extreme temperatures. During the research period, it was noticed that the frosts which may occur during the 
second half of April and at the beginning of May, before foliation, can cause significant injuries to beech plantlets.

\section{References}

Berbecel, O., ş. a., 1971: Agrometeorologie. Editura Ceres, Bucureşti.

Bodnariuc, N., Vădineanu, A., 1982: Ecologie generală. Editura Didactică şi pedagogică, București.

Brega, P., 1992: Problematica regenerării amestecurilor de răşinoase şi fag. Revista Pădurilor, no. 1.

Chiriţă, C., D., 1974: Ecopedologia. Editura Academiei R. S. R.

Chiriţă, C., D., ş. a., 1977: Stațiuni forestiere. Editura Academiei R. S. R.

Chiriţă, C., D., Doniţă, N., Ivănescu, D., Lupe, I., Milescu, I., Stănescu, V., Vlad, I. s.. a., 1981: Pădurile României. Editura Academiei Republicii Socialiste România, Bucureşti.

Ciobanu, P., Bândiu, C., Vlonga, St., 1988: Contribuții la cunoașterea regimului ecologic şi punctelor de regenerare circulare în brădeto-făgete. Sesiunea de comunicări ştiințifice a Facultăţii de Silvicultură şi Exploatări Forestiere din Braşov.

Constantinescu, N., 1963 (1973): Regenerarea arboretelor. Editura Agro-silvică. Bucureşti (Editura Ceres Bucureşti).

Covrig, I., 2000: Efectul microclimatic al unor lucrări silvotehnice asupra regenerării fagului. A IV-a Sesiune Ştiințifică, Ecologia şi protecţia ecosistemelor, Universitatea Bacău - Secţia Biologie.

Covrig I, 2013, Regenerarea fagului, Editura Bioflux Cluj-Napoca, ISBN 978-6068191-59-1

Hanganu, C., 1963: Referitor la regenerarea făgetelor. Revista Pădurilor, no. 1.

Marcu, M., 1962: Cercetări asupra posibilităţilor de producere a ingheturilor târzii şi timpurii, în scopul prevenirii efectului dăunător al acestora asupra culturilor forestiere. Lucrare ştiinţifică I. P. Braşov, vol. V.

Marcu, M., 1970: Cercetări privind regenerarea naturală în făgete, pădurea WartheBraşov. Buletin I. P. Braşov., vol. XII.

Milescu, I., Alexe, A., 1967: Fagul. Editura Agro-Silvică, Bucureşti.

Săvulescu, Al., Negruțiu, A., Crețianu, I., Văcaru, Gh., 1967: Cercetări privind regenerarea pe cale naturală a fagului în urma aplicării tăierilor rase în benzi la DREF Braşov. Buletinul Institutului Politehnic Braşov, seria B, vol. IX.

Teissier du Cros, E., ş.a., 1981: Le hetre. Institut National de la Recherche Agronomique, Departement des Recherches Forestieres.

***, 1996: La gestion durable des forets: contribution de la recherche. Institut National de la Recherche Agronomique, no. 12. 